\title{
Detection of mycobacterial DNA in pleural fluid from patients with tuberculous pleurisy by means of the polymerase chain reaction: comparison of two protocols
}

Arnaud de Lassence, Denise Lecossier, Catherine Pierre, Jacques Cadranel, Marc Stern, Allan J Hance

\begin{abstract}
Background The detection of mycobacterial DNA in clinical samples on the basis of the polymerase chain reaction is a promising approach for the rapid diagnosis of tuberculous infections. No consensus exists, however, about which protocols are most sensitive, and the usefulness of this approach in the diagnosis of tuberculous effusions has been assessed in few patients.
\end{abstract}

Methods The sensitivity of two protocols was compared for the detection of DNA from Mycobacterium tuberculosis in samples containing known amounts of mycobacterial DNA and in DNA extracted from 15 tuberculous pleural effusions. The results obtained for pleural fluid have been compared with cytological findings and with results obtained by standard microbiological techniques.

Results Mycobacteria could be detected by acid fast staining in none and by culture in three of the $\mathbf{1 5}$ pleural fluid samples. A protocol based on the detection of the IS6110 insertion element (which could detect one mycobacterial genome/sample reproducibly) gave a positive result in nine of the 15 tuberculous effusions, though some samples were only intermittently positive ( $p<0.05$ compared with culture). In contrast, a protocol based on the detection of the gene coding for the $65 \mathrm{kD}$

INSERM U 82, Faculté de Médecine Xavier Bichat

A de Lassence

D Lecossier

C Pierre

A J Hance

Service de Pneumo-

phtisiologie et

Réanimation

Respiratoire, Hôpital

Tenon

J Cadranel

Service de

Pneumologie Hôpital

Foch

M Stern

Paris, France

Reprint requests to: Dr A J Hance

Accepted 1 December 1991 mycobacteria (possibly neutrophils) before DNA extraction may be required to improve the sensitivity of this approach.

Attempts to identify Mycobacterium tuberculosis in pleural fluid from patients with tuberculous pleurisy by acid fast staining is usually unrewarding, and culture of pleural fluid for mycobacteria is also negative in a substantial number of cases. ${ }^{12}$ Because mycobacterial cultures of pleural fluid cannot be relied on to provide a diagnosis, the investigation of a patient with a pleural effusion suspected of having tuberculosis usually includes a search for mycobacteria at other sites, including specimens of pleura obtained by pleural biopsy. ${ }^{3}$ Thus the development of diagnostic procedures capable of rapidly identifying $M$ tuberculosis in pleural fluid from most patients remains a worthwhile goal.

Recently we and others have developed techniques for the detection of mycobacterial DNA in clinical samples using techniques based on the polymerase chain reaction. ${ }^{4-14}$ This approach is sufficiently sensitive to detect DNA from $M$ tuberculosis in clinical specimens producing negative routine cultures, including in some cases specimens of pleural fluid. ${ }^{58111415}$ Several different mycobacterial DNA sequences have been amplified in these studies. It has been suggested that those systems that amplify sequences present in multiple copies in the mycobacterial genome may be more sensitive that those that amplify targets present in a single copy ${ }^{7-10} 15$ The relative sensitivity of the different protocols has not been rigorously compared, however. Thus, although the detection of mycobacterial DNA after amplification appears to have considerable promise in the diagnosis of tuberculous infections, no consensus exists about which procedures are most sensitive.

In this study we have compared the sensitivity of two different protocols for the detection of DNA from $M$ tuberculosis, one based on the detection of a sequence coding for the $65 \mathrm{kD}$ mycobacterial antigen, present in a single copy in the mycobacterial genome ${ }^{16}$ and a second procedure based on 
the detection of the IS6110 insertion element, ${ }^{17}$ present in multiple copies. ${ }^{91015}$ Both systems are designed to detect all organisms belonging to the $M$ tuberculosis complex, but not other mycobacterial species. ${ }^{4915}$ In initial studies the sensitivities were compared by using standards containing known amounts of mycobacterial DNA. In addition, we have assessed the usefulness of the two systems in the diagnosis of tuberculous pleural effusions, and have compared the results obtained by DNA amplification with cytological findings and results obtained by standard microbiological techniques.

\section{Methods}

PATIENT GROUPS

Patients with a tuberculous effusion

Samples of pleural fluid from 14 patients with a tuberculous effusion were studied. In 13 patients the diagnosis of tuberculosis was established on the basis of one or more of the following criteria: culture of sputum $(n=6)$, pleural fluid $(n=5)$, or pleural biopsy specimen $(n=4)$ positive for $M$ tuberculosis or the presence of caseating granulomas in a pleural biopsy specimen $(n=9)$. In one patient the diagnosis was based on a history of recent exposure to a patient with active tuberculosis, the presence of a lymphocytic pleural exudate, and a favourable response to antituberculous drugs. Two different samples of pleural fluid from one patient were studied by the polymerase chain reaction method. In two cases the sample of pleural fluid giving positive results in culture was different from that evaluated in this study. None of the patients had a positive result in the serological test for human immunodeficiency virus or had any other disease known to produce immunosuppression. None was receiving antituberculous drugs. Differential cell counts for the pleural fluid were available for 14 of the 15 samples.

\section{Control subjects}

Ten samples of pleural fluid were obtained from patients with a pleural effusion resulting from malignant intrathoracic neoplasms. None of these patients had a past history of tuberculosis, and culture of pleural fluid was negative for $M$ tuberculosis and other organisms.

Table 1 Sequence of oligonucleotides used in this study

\begin{tabular}{|c|c|}
\hline Oligonucleotide & Sequence \\
\hline \multicolumn{2}{|c|}{$\begin{array}{l}65 \mathrm{kD} \text { MYCOBACTERIAL ANTIGEN } \\
\text { Amplification primers }\end{array}$} \\
\hline $\begin{array}{r}1 \\
2 \\
28 \\
29 \\
38 \\
39\end{array}$ & $\begin{array}{l}\text { 5'-GAGATCGAGCTGGAGGATCC } \\
\text { 5'-AGCTGCAGCCCAAAGGTGTT } \\
\text { 5'-CCGAGACCCTGCTCAAGGGC } \\
\text { 5'-CCTCCTCGACGGTGATGACG } \\
\text { 5'-CGCTCCGGGTCGGTCACGAA } \\
\text { 5'-CCGTGCTGGCCCAGGCGTTG }\end{array}$ \\
\hline $\begin{array}{l}\text { Hybridisation pr } \\
12\end{array}$ & 5e \\
\hline $\begin{array}{l}\text { IS6110 INSERTION } \\
\text { Amplification pr } \\
\text { IS1 } \\
\text { IS2 }\end{array}$ & $\begin{array}{l}\text { SEQUENCE } \\
\text { mers } \\
\text { 5'-CCTGCGAGCGTAGGCGTCGG } \\
\text { 5'-CTCGTCCAGCGCCGCTTCGG }\end{array}$ \\
\hline $\begin{array}{l}\text { Hybridisation p } \\
\text { IS } 3\end{array}$ & $\begin{array}{l}\text { be } \\
\text { 5'-CTGCCCAGGTCGACACAT }\end{array}$ \\
\hline
\end{tabular}

\section{EXTRACTION OF DNA}

For extraction of DNA $10-20 \mathrm{ml}$ of pleural fluid was centrifuged ( $1850 \mathrm{~g}$ for 20 minutes), the supernatant removed, and DNA extracted from the cell pellet by the technique described by Patel et $a l^{18}$ with minor modifications. DNA was quantified by measuring the optical density at $260 \mathrm{~nm}$.

\section{AMPLIFICATION OF MYCOBACTERIAL DNA}

Oligonucleotides were synthesised with a $381 \mathrm{~A}$ DNA Synthesizer (Applied Biosystems, Foster City, California) and purified by ethanol precipitation. The sequences for oligonucleotides used are summarised in table 1 .

DNA amplification was performed as described. ${ }^{19}$ All reactions contained $10 \mathrm{mM}$ tris- $\mathrm{HCl}(\mathrm{pH} 8.3), 50 \mathrm{mM} \mathrm{KCl}, 100 \mu \mathrm{g} / \mathrm{ml}$ gelatin, $0.3 \mathrm{mM}$ of each dNTP, $25 \mathrm{pmol}$ of each oligonucleotide primer, $50 \mathrm{U} / \mathrm{ml} T a q$ polymerase (Stratagene, La Jolla CA), 1 unit Perfect Match polymerase enhancer (Stratagene), and $500 \mathrm{ng}$ template DNA in a final volume of $50 \mu \mathrm{l}$. Reagents were heated to $80^{\circ} \mathrm{C}$ before DNA was added, to decrease nonspecific annealing of oligonucleotides to the template DNA. ${ }^{20}$

To amplify a fragment of the gene coding for the $65 \mathrm{kD}$ mycobacterial antigen, the reamplification protocol described by Pierre $e t \mathrm{al}^{6}$ was used, except that the oligonucleotide primer pair $39 / 2$ or $39 / 38$ was used during the initial amplification. The cycle was $94^{\circ} \mathrm{C} / 40$ seconds, $55^{\circ} \mathrm{C} / 40$ seconds, and $72^{\circ} \mathrm{C} / 15$ seconds ( 50 cycles). The sensitivity of detection of DNA in positive control samples was not significantly different with the two pairs of primers (data not shown), and the results obtained with the two systems are presented together.

For amplification of a fragment of the IS6110 insertion element the oligonucleotides described by Eisenach et al $^{9}$ were used (oligonucleotides IS $1 /$ IS 2 ). The cycle was $94^{\circ} \mathrm{C} / 40$ seconds, $65^{\circ} \mathrm{C} / 40$ seconds, $72^{\circ} \mathrm{C} / 15$ seconds (50 cycles).

Positive control samples, included in all experiments, were prepared by diluting purified DNA from $M$ tuberculosis (ATCC 27294) with a solution of purified human DNA that did not contain detectable mycobacterial DNA to produce standards containing 20 and 2 mycobacterial genomes $/ 1 \mu \mathrm{g}$ total DNA, on the assumption of a molecular weight of $2.5 \times 10^{9}$ daltons/genome. ${ }^{21}$ Negative control samples (samples without added DNA) were included in all experiments.

To test the extraction procedure, known numbers of intact Mycobacterium bovis BCG organisms (Pasteur strain 1173-P2) grown in dispersed culture were added to a control tissue sample. DNA was extracted as described above and diluted with purified human DNA to produce standards containing about 10 mycobacterial genomes/ $\mu$ g total DNA (on the assumption that all mycobacterial DNA was recovered during the extraction process). 
Table 2 Sensitivity of detection of known amounts of mycobacterial DNA (number of positive results/total attempts)

\begin{tabular}{|c|c|c|c|}
\hline \multirow[b]{2}{*}{ Target sequence } & \multicolumn{3}{|c|}{ Amount of mycobacterial DNA/sample DNA } \\
\hline & 10 genomes & 1 genome & No added DNA \\
\hline $\begin{array}{l}65 \mathrm{kD} \text { mycobacterial antigen } \\
\text { Insertion element IS } 6110\end{array}$ & $\begin{array}{l}13 / 16 \\
22 / 22\end{array}$ & $\begin{array}{l}0 / 10 \\
7 / 7\end{array}$ & $\begin{array}{l}0 / 18 \\
0 / 14\end{array}$ \\
\hline
\end{tabular}

DNA sequences was detected as previously described. ${ }^{45}$ Briefly, aliquots of the amplification products were electrophoresed into $2 \%$ agarose gels. The DNA was transferred to nylon membranes and hybridised with $3 \times 10^{5}$ $\mathrm{cpm} / \mathrm{ml}\left[{ }^{32} \mathrm{P}\right]-5^{\prime}-$ labelled (specific activity 1-3 $\mathrm{mCi} / \mathrm{pmol}$ ) oligonucleotide, washed, and exposed to radiographic film. Oligonucleotide 12 was used to detect amplified fragments of the gene coding for the $65 \mathrm{kD}$ mycobacterial antigen (stringent washing at $59^{\circ} \mathrm{C}$ for five minutes) and oligonucleotide IS 3 was used to detect amplified fragments of the IS6110 sequence (stringent wash at $58^{\circ} \mathrm{C}$ for five minutes). A sample was considered positive if a signal corresponding to an amplified product of the appropriate size was seen in autoradiograms exposed for 18 hours. Preliminary studies showed that exposing autoradiograms for three hours was not sufficient to obtain maximum sensitivity; extending the exposure beyond 18 hours did not result in further improvement of sensitivity. Faint or ambiguous signals were not observed in autoradiograms exposed for 18 hours.

\section{STATISTICAL ANALYSIS}

All samples were tested three times in independent experiments. Comparisons of positive results were made by the $\chi^{2}$ test. Cell types present in pleural fluid samples were compared by the Mann-Whitney test.

\section{Results}

COMPARISON OF THE SENSITIVITY OF DIFFERENT AMPLIFICATION PROTOCOLS

In preliminary experiments solutions of human
DNA containing known amounts of DNA from $M$ tuberculosis were prepared and amplified by means of two different amplification protocols (table 2).

To detect mycobacterial DNA coding for the $65 \mathrm{kD}$ antigen, samples were first amplified and the amplification products reamplified by the use of the "nested" primers, which recognise sequences contained within the originally amplified fragment. ${ }^{6}$ This system usually gave positive results for samples containing 10 mycobacterial genomes per sample, but was uniformly negative for samples containing one genome per sample. Samples without added DNA were also negative.

To detect the mycobacterial insertion element IS6110, samples were amplified by the use of the primer pair IS1/IS2. ${ }^{7}$ This system always gave positive results for control samples containing one or more genomes per sample ( $p<0.001$ for the difference in the sensitivity of detection of the insertion sequence IS6110 and the sequence coding for the $65 \mathrm{kD}$ antigen). Samples without added DNA were always negative.

The procedure used to purify DNA appeared to extract mycobacterial DNA efficiently, in that a control specimen, which would have contained about 10 genomes of mycobacterial DNA per sample (on the assumption of complete recovery of mycobacterial DNA), was always positive with the two different amplification protocols (10/10 and 4/4 positive results with systems based on amplification of the $65 \mathrm{kD}$ antigen and IS 6110 insertion element respectively).

\section{DETECTION OF MYCOBACTERIAL DNA IN PLEURAL} FLUID

All samples of pleural fluid from patients with a tuberculous effusion were negative for mycobacteria on direct microscopic examination; three of the 15 samples produced a culture positive for $M$ tuberculosis (table 3). DNA was extracted from the same samples, and the presence of mycobacterial DNA assessed by

Table 3 Comparison of the results of standard diagnostic tests and those obtained by amplification of mycobacterial DNA (number of positive results/3 initial attempts) in the diagnosis of tuberculous pleurisy

\begin{tabular}{|c|c|c|c|c|c|c|c|c|c|}
\hline \multirow{3}{*}{$\begin{array}{l}\text { Sample } \\
\text { No }\end{array}$} & \multicolumn{7}{|c|}{ Standard diagnostic tests ${ }^{\star}$} & & \\
\hline & \multicolumn{2}{|c|}{ Pleural fluid } & \multicolumn{3}{|c|}{ Pleural biopsy specimen } & \multicolumn{2}{|c|}{ Sputum } & \multicolumn{2}{|c|}{ Amplification of mycobacterial DNA } \\
\hline & Stain & Culture & Stain & Culture & Histology & Stain & Culture & $65 \mathrm{kD}$ antigen & IS6110 \\
\hline 1 & - & + & ND & ND & - & - & + & $3 / 3$ & $3 / 3$ \\
\hline 2 & - & + & - & + & + & + & + & $3 / 3$ & $3 / 3$ \\
\hline 3 & - & - & - & ND & + & - & - & $3 / 3$ & $3 / 3 \dagger$ \\
\hline 4 & - & - & - & - & - & - & - & $0 / 3$ & $3 / 3$ \\
\hline 5 & - & - & - & ND & + & - & - & $0 / 3$ & $3 / 3 \dagger$ \\
\hline 6 & - & + & - & - & - & - & - & $0 / 3$ & $2 / 3$ \\
\hline 7 & - & - & - & - & + & - & + & $0 / 3$ & $1 / 3$ \\
\hline 8 & - & - & - & ND & + & - & + & $0 / 3$ & $1 / 3$ \\
\hline 9 & - & - & - & ND & + & - & - & $0 / 3$ & $1 / 3$ \\
\hline 10 & - & - & - & ND & - & - & - & $0 / 3$ & $0 / 3$ \\
\hline 11 & - & - & - & + & + & + & + & $0 / 3$ & $0 / 3$ \\
\hline 12 & - & - & - & ND & + & - & - & $0 / 3$ & $0 / 3$ \\
\hline 13 & - & - & - & ND & + & - & - & $0 / 3$ & $0 / 3$ \\
\hline 14 & - & - & - & - & - & - & - & $0 / 3$ & $0 / 3$ \\
\hline 15 & - & - & - & + & + & - & + & $0 / 3$ & $0 / 3$ \\
\hline
\end{tabular}

*Stain-presence or absence of acid fast organisms on Ziehl-Neelsen stained material. Histology-presence or absence of typical granulomatous lesions. For pleural fluid only the results obtained for the sample assessed by the polymerase chain reaction are given. For sputum 3-11 samples were evaluated for each patient; + indicates one or more positive results. †From the same patient. 
Comparison of the results of the polymerase chain reaction and the cytological findings in pleural fluid from patients with tuberculosis:

percentages of neutrophils (left), macrophages (centre), and lymphocytes (right) in pleural fluid for specimens that were

positive on $3 / 3$

amplifications $(A), 2 / 3$ or $1 / 3$ amplifications $(B)$, and $0 / 3$ amplifications $(C)$ with the system detecting the IS6110 insertion element. Samples that were also positive with the amplification system detecting the gene coding for the $65 k D$ mycobacterial antigen are indicated by solid symbols.
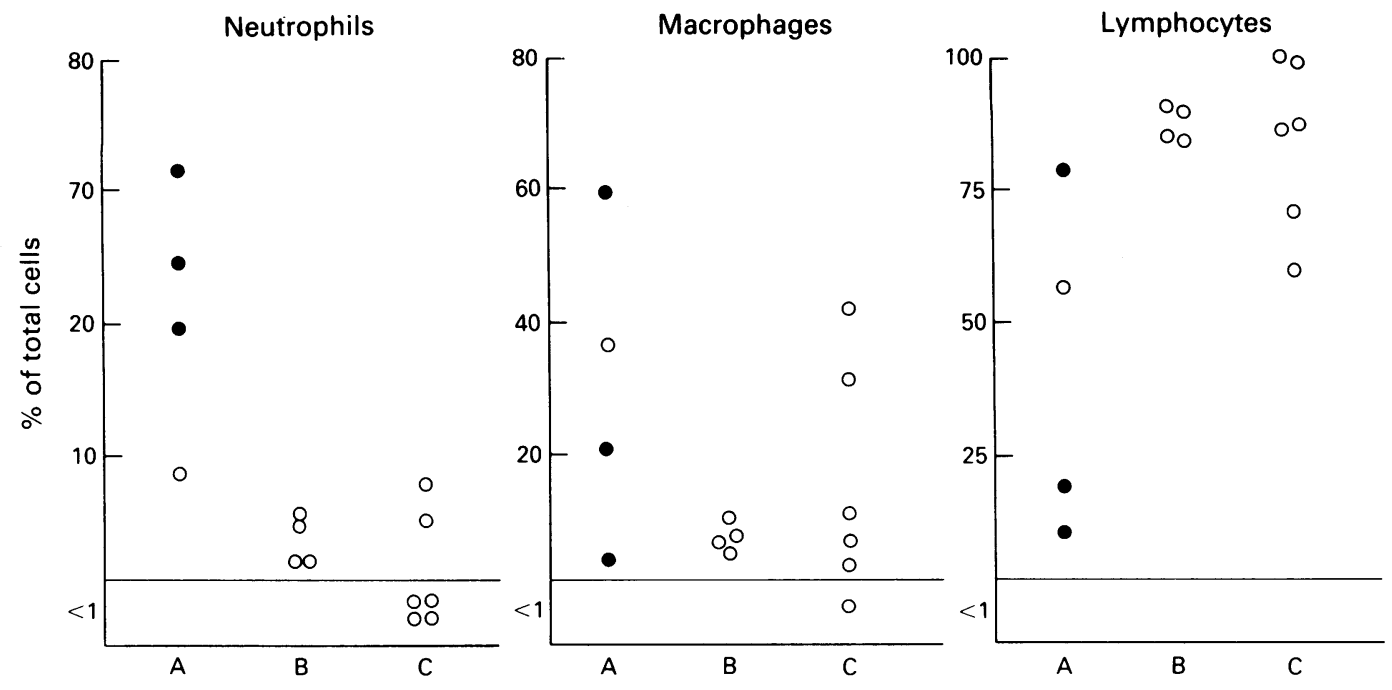

amplification of the insertion sequence IS6110 in three independent experiments. Positive results were obtained for $9 / 15$ patients (table 3 ), including all three patients whose fluid was positive by culture $(\mathrm{p}<0.05$ for the difference in sensitivity of the amplification protocol and culture). In three of the nine cases only one of the three experiments gave a positive result. When the amplification procedure was repeated three more times for these patients a positive result was observed in $1 / 3,1 / 3$, and $0 / 3$ samples respectively. Pleural fluid from patients without mycobacterial infection gave negative results by the amplification procedure in all cases when it was tested in three or more independent experiments (data not shown).

When DNA from a tuberculous effusion was tested with the reamplification protocol for detection of the gene coding for the $65 \mathrm{kD}$ antigen, positive results were obtained for $3 / 15$ samples (table $3 ; p<0.05$ for the difference in sensitivity of detection of the $65 \mathrm{kD}$ antigen and the IS6110 insertion sequence). The three samples that were positive with this test were among those that were always positive in experiments detecting the IS6110; two of these samples were also positive by culture.

\section{COMPARISON OF CYTOLOGICAL FINDINGS WITH} RESULTS OF DNA AMPLIFICATION

Lymphocytes were the predominant cell type observed in most pleural fluid samples (mean $73 \%$ (SD $28 \%$ ) lymphocytes, $n=14$ ), though neutrophils and other mononuclear cells were present in variable numbers. Strikingly, the percentage of neutrophils in fluid that was always positive with the protocol based on the detection of the IS6110 insertion sequence $(30 \%(27 \%)$ neutrophils) was significantly higher than that present in samples that were intermittently positive $(3 \%(2 \%)$ neutrophils) or always negative (2\% (3\%) neutrophils) with the same protocol (figure; $p<0.01$ ). Mycobacterial DNA was never detected in any of the four samples that contained less than $1 \%$ neutrophils. Similarly, the three samples of pleural fluid in which mycobacterial DNA could be detected with the protocol based on the detection of the $65 \mathrm{kD}$ mycobacterial antigen all contained abundant neutrophils $(71 \%, 24 \%$, and $18 \%)$.

\section{Discussion}

In this study mycobacterial DNA was rapidly detected by means of the polymerase chain reaction in nine of 15 samples of pleural fluid from patients with a tuberculous effusion, despite the fact that many of the samples did not grow $M$ tuberculosis in culture. This finding confirms several recently published reports showing the potential usefulness of this approach in detecting mycobacterial DNA in pleural and cerebrospinal fluid from patients with tuberculosis. 8111415

The protocol used to detect the IS6110 insertion sequence was more sensitive than the protocol used to detect the gene coding for the $65 \mathrm{kD}$ mycobacterial antigen. This is probably explained by the fact that the IS6110 is present in 10-15 copies in each mycobacterial genome, whereas the gene coding for the $65 \mathrm{kD}$ antigen is probably present in a single copy..$^{91015}$ The increased sensitivity afforded by the detection of the IS6110 insertion sequence considerably improves the yield for the detection of mycobacterial DNA in pleural fluid. Because this insertion sequence is present only in mycobacteria of the $M$ tuberculosis complex, positive results are not observed for other species of mycobacteria. ${ }^{915}$

Our findings also indicate that the number of mycobacteria present in tuberculous effusions is often quite low. The gene coding for the $65 \mathrm{kD}$ mycobacterial antigen could be detected in only three of 15 samples by using a system that had a sensitivity of about 10 mycobacterial genomes/sample. In contrast, if the amplification procedure was repeated at least three times the IS6110 insertion sequence could be detected in nine of the 15 samples with the detect one mycobacterial genome per sample reproducibly. As all samples contained $500 \mathrm{ng}$ of total DNA (equivalent to $7 \times 10^{4}$ human cells), these findings suggest that most pleural fluid contains at least $1-20$ mycobacteria $/ 10^{6}$ human cells, but that only a few pleural system described by Eisenach et $a l^{9}$; this can 
effusions contain over 200 mycobacteria $/ 10^{6}$ human cells.

We would emphasise that some specimens were positive only intermittently when tested on multiple occasions. The presence of inhibitors could not be detected in such samples (data not shown). The results probably indicate that the levels of mycobacterial DNA present in such fluid are so low that a given aliquot may or may not contain an amplifiable target. We have recently found that with the IS6110 system a standard DNA solution containing, on average, $0 \cdot 1$ mycobacterial genome (that is, 1-1.5 targets/sample with the IS6110 system) will give a positive result in about half the tests (Pierre et al, unpublished findings). Further studies are needed to define how many times a given sample must be amplified to obtain optimal sensitivity without sacrificing specificity. The findings in this and other studies in our laboratory suggest, however, that if two or possibly three attempts give negative results for a particular specimen little is to be gained by further attempts.

An interesting finding in our study was that all pleural fluid samples that were positive with the protocol based on the detection of the $65 \mathrm{kD}$ mycobacterial antigen, and are therefore likely to have contained a relatively large number of mycobacteria, also contained a high percentage of neutrophils. Samples that were always positive with the protocol based on the detection of the IS6110 insertion sequence had more neutrophils than samples that were intermittently positive or always negative. All four samples that contained less than $1 \%$ neutrophils were always negative when tested for the presence of mycobacterial DNA. These results are consistent with the possibility that the number of neutrophils present in a given sample may reflect the number of mycobacteria present, a finding that could be explained by the chemotaxis of neutrophils toward products released by extracellular mycobacteria. The substantial variability in the number of neutrophils (and mycobacteria) present in these fluid samples could reflect variations in the time between onset of the tuberculous effusion and assessment ${ }^{22}{ }^{23}$ or differences in the pathogenesis of tuberculosis in these patients (for example, late primary tuberculosis versus reactivation)-or both. ${ }^{24}$

If the neutrophils present in tuberculous effusions actively phagocytose the mycobacteria in the pleural fluid, the isolation of neutrophils from these fluid samples might offer a convenient means of enriching the proportion of mycobacterial DNA present in a given sample. This might be particularly useful for samples containing few neutrophils (for example, the samples for which the amplification procedure was frequently negative). As the amplification procedure is limited by the amount of total DNA that can be evaluated, enrichment of cells containing mycobacteria before the extraction of DNA might improve the sensitivity of the test for these difficult samples.

In conclusion, the amplification of the IS6110 insertion element permitted the detection of mycobacterial DNA in nine of 15 patients with a tuberculous effusion. Further studies are clearly warranted to define the role of this test in the assessment of patients with pleural effusion of unknown aetiology.

1 Sahn SA. The pleura. Am Rev Respir Dis 1988;138:184-234. 2 Berger HW, Meija E. Tuberculous pleurisy. Chest 1973;63:88-92.

3 Levine H, Metzger W, Lacera D, Kay L. Diagnosis of tuberculous pleurisy by culture of pleural biopsy specimens. Arch Intern Med 1970;126:269-71.

4 Hance AJ, Grandchamp B, Lévy-Frébault V, Lecossier D, Rauzier J, Bocart D, et al. Detection and identification of mycobacteria by amplification of mycobacterial DNA. Molec Microbiol 1989;3:843-9.

5 Brisson-Noël A, Gicquel G, Lecossier D, Lévy-Frébault V, Nassif X, Hance AJ. Rapid diagnosis of tuberculosis by amplification of mycobacterial DNA in clinical samples. Lancet 1989;ii:1069-71.

6 Pierre C, Lecossier D, Boussougant Y, Bocart D, Joly V, Yeni $\mathrm{P}$, et al. Use of a reamplification protocol improves sensitivity of detection of Mycobacterium tuberculosis in clinical samples by amplification of DNA. J Clin Microbiol (in press).

7 Böddinghaus B, Rogall T, Flohr T, Blöcker H, Böttger EC. Detection and identification of mycobacteria by amplification of rRNA. J Clin Microbiol 1990;28:1751-9.

8 De Wit D, Steyn L, Shoemaker S, Sogin M. Direct detection of Mycobacterium tuberculosis in clinical specimens by DNA amplification. J Clin Microbiol 1990;28:2437-41.

9 Eisenach KD, Cave MD, Bates JH, Crawford JT. Polymerase chain reaction amplification of a repetitive DNA sequence specific for Mycobacterium tuberculosis. $J$ Infect Dis 1990;161:977-81.

10 Hermans PWM, van Soolingen D, Dale JW, Schuitema ARJ, McAdam RA, Catty D, et al. Insertion element IS 986 from Mycobacterium tuberculosis: a useful tool for diagnosis and epidemiology of tuberculosis. J Clin Microbiol 1990;28:2051-8.

11 Pao CC, Yen B, You JB, Maa JS, Fiss EH, Chang CH. Detection and identification of Mycobacterium tuberculosis by DNA amplification. J Clin Microbiol 1990;28:1877-80.

12 Patel RJ, Fries JWU, Piessens WF, Wirth DF. Sequence analysis and amplification by polymerase chain reaction of a cloned DNA fragment for identification of Mycobacterium tuberculosis. J Clin Microbiol 1990;28:513-8.

13 Plikaytis BB, Gelber RH, Shinnick TM. Rapid and sensitive detection of Mycobacterium leprae using a nested-primer gene amplification assay. J Clin Microbiol 1990;28:1913-7.

14 Shankar P, Manjunath N, Mohan KK, Prasad K, Behari M, Shriniwas, et al. Rapid diagnosis of tuberculous meningitis by polymerase chain reaction. Lancet 1991;337:5-7.

15 Thierry D, Brisson-Noël A. Vincent-Lévy-Frébault V, Nguyen S, Guesdon J-L, Gicquel B. Characterization of a Mycobacterium tuberculosis insertion sequence, IS6110, and its application in diagnosis. J Clin Microbiol 1990; 28:2668-73.

16 Shinnick TM. The 65-kilodalton antigen of Mycobacterium tuberculosis. J Bacteriol 1987;169:1080-8.

17 Thierry D, Cave MD, Eisenach KD, Crawford JT, Bates $\mathrm{JH}$, Gicquel B, et al. IS6110, an IS-like element of Mycobacterium tuberculosis complex. Nucleic Acids Res 1990;18:188-9.

18 Patel R, Kvach JT, Mounts P. Isolation and restriction endonuclease analysis of mycobacterial DNA. J Gen Microbiol 1984;132:541-51.

19 Mullis KB, Faloona FA. Specific synthesis of DNA in vitro via a polymerase catalyzed chain reaction. Methods Enzymol 1987;155:335-50.

20 Erlich HA, Gelfand D, Sninsky JJ. Recent advances in the polymerase chain reaction. Science 1991;252:1643-50.

21 Baess I. Determination and re-examination of genome sizes and base ratios in deoxyribonucleic acid from mycobacteria. Acta Pathol Microbiol Immunol Scand Sect B 1984;92:209-11.

22 Antony VB, Repine JE, Harada RN, Good JT, Sahn SA. Inflammatory responses in experimental tuberculous pleurisy. Acta Cytol 1983;27:355-61.

23 Levine H, Szanto PB, Cugell DW. Tuberculous pleurisy: an acute illness. Arch Intern Med 1968;122:329-32.

24 Antoniskis D, Amin K, Barnes PF. Pleuritis as a manifestation of reactivation tuberculosis. Am J Med 1990;89: 447-50. 